\title{
IDENTIFIKASI GULMA TANAMAN PADI (Oryza sativa L. var. Ciherang) SUMATARA SELATAN
}

Syarifa ${ }^{1}$, Ike Apriani ${ }^{2}$, Ra Hoetary Tirta Amallia ${ }^{3}$

${ }^{123}$ Universitas Islam Negeri Raden Fatah Palembang Jl. Prof. K.H. Zainal Abidin Fikri No. 1 A

KM 3,5, Palembang 30126, Indonesia

*Corresponding author, e-mail: syarifah_uin@radenfatah.ac.id

\section{ABSTRACT}

The growth of weeds in the rice fields can reduce production. Weed is a disrupting plant that grows and spreads rapidly so it becomes a nutritional competitor for cultivated plants. This study aims to identify rice weeds in the fields of Rimau District, Banyuasin, South Sumatra. The research method used was descriptive method with purposive sampling on wetland rice fields of the Ciherang variety. Sampling was carried out in a critical period (3-6 weeks after planting) in rice fields. The results of weed identification obtained 6 families consisting of 15 species, namely Ageratum conyzoides L., Crassocephalum crepidioides, Cleome rutidisprema DC., Cyperusroduntus L. Cyperus compressus, Eleocharis palustris L., Frimbristylis miliacea L. Vahl, Phylanthus naruri L., Eurphobia hirta, Cynodon dactylon (L.) Press., Digitaria ciliaris (Retz.) Koel., Echinochola colona (L.) Link., Eleusinindica (L.) Gaertn., Paspalum scrobiculatum L., Ludwigia octovalvis (Jacq.) Raven. The Poaceae family is most commonly found as a rice weed in Rimau District, South Sumatra.

Keywords: Weeds, Identification, Oryza sativa L, South Sumatra

\section{PENDAHULUAN}

Beras merupakan makanan pokok bagi masyarakat Indonesia (Miranda, dkk., 2011). Jumlah penduduk Indonesia yang mencapai 255,46 juta orang dengan laju pertumbuhan sebesar 1,31\% memerlukan konsumsi beras mencapai 124,89 $\mathrm{kg} / \mathrm{kapita} / \mathrm{tahun}$ (Pertanian, 2016). Salah satu Kabupaten yang menjadi lumbung padi di Sumatera Selatan adalah Kabupaten Banyuasin. Kabupaten ini merupakan penghasil padi terbesar di Sumatera Selatan, pada tahun 2016, total produksi mencapai 1.4 juta ton Gabah Kering Giling (GKG). Berdasarkan data statistik pertanian (SP), tahun 2015, Banyuasin memiliki luas tanam padi berkisar 197.961 ha.

Kebutuhan pangan yang cukup besar diupayakan dengan peningkatan produksi beras diantaranya dengan pemilihan varietas padi tahan hama seperti Ciherang. Varietas Ciherang memiliki daya tahan terhadap penyakit HBD (kresek), mempunyai potensi hasil yang tinggi (kisaran 8-9 t/ha), mempunyai rasa nasi yang pulen dan sangat sesuai dikembangkan di lahan sawah irigasi dataran rendah (Pertanian B. L., 2012) sehingga varietas ini banyak ditanam di Banyuasin, Sumatera Selatan.

Organisme pengganggu di lahan persawahan tidak hanya dari hama maupun bakteri tetapi ada tanaman gulma yang berpotensi menurunkan produktivitas padi. Tanaman gulma di lahan pertanian memberikan dampak negatif terhadap tanaman budidaya, baik secara langsung maupun tidak langsung dan dapat menurunkan hasil 
produksi (Antralina, 2012). Salah satu permasalahan yang sering ditemukan di lapangan yang sangat barpengaruh terhadap produktivitas padi adalah gulma, karena gulma sampai saat ini masih banyak tumbuh di sekitar areal pertanaman padi yang bersifat sebagai pengganggu, sehingga menyebabkan penurunan produksi padi. Keberadaan gulma dapat mengurangi produksi sawah padi sekitar $17 \%$ dan padigogo $\pm 40 \%$. Gulma akan menyaingi tanaman budidaya dalam pengambilan unsur hara, air, ruang, $\mathrm{CO}_{2}$ dan cahaya (Bangun, 1993). Beberapa jenis gulma dapat mengeluarkan zat allelopati yang bersifat toksik sehingga menyebabkan terganggunya pertumbuhan tanaman di sekitar dan dapat menjadi inang hama dan patogen (Sarifin, dkk., 2017; Aldrich, 1984). Gulma memiliki system perakaran yang sama dengan tanaman padi, sehingga unsur makanan yang diperlukan oleh gulma dan padi berasal dari lapisan tanah yang sama. Oleh karena itu, terjadi persaingan dalam mendapatkan zat makanan (Harnel, 2011)

Kompetisi antara tanaman budidaya dan gulma tidak mematikan tanaman pokok namun dapat menyebabkan kerugian bagi usaha pertanian, kompetisi dalam perebutan unsur hara dan air dapat meningkatkan komponen produksi (Sundaru, dkk., 1976). Selain itu, biaya pengendalian gulma cukup besar dan seringkali lebih mahal dari biaya pengendalian hama dan penyakit. Dengan demikian perlu dilakukan pengendalian gulma yang tepat. Identifikasi jenis-jenis gulma akan membantu dalam proses pengendalian gulma.

Perlu dilakukan identifikasi terhadap gulma yang ada di lahan sawah padi di Sumatera Selatan. Hasil identifikasi dapat membantu dalam mengatasi dan menghambat pertumbuhan gulma di lahan pertanian serta dapat mengetahui potensi dari gulma tersebut. (Biogen, 2000) menjelaskan bahwa identifikasi merupakan kegiatan dalam rangka melihat, mengamati, dan mencatat sifat-sifat penting yang bernilai ekonomis atau merupakan penciri dari individu yang bersangkutan.

\section{METODE}

Penelitian dilakukan pada bulan Juni 2017 di lahan pertanian padi varietas Ciherang Kecamatan Rimau, Banyuasin, Sumatera Selatan. Alat yang digunakan adalah tali rapiah, cangkul, alat tulis, tiang pancang, kamera. Bahan yang digunakan adalah gulma di lahan sawah padi varietas ciherang. Metode yang digunakan adalah deskriptif dengan pengambilan sampel (gulma) secara sengaja (purposive sampling). Prosedur Pengambilan Sampel meliputi: Survey Pendahuluan, Penentuan Titik Sampel, Teknik Pengambilan Sampel. Pengambilan sampel gulma dilakukan pada 3-6 minggu setelah penanaman (fase vegetatif) padi, pada minggu ini kondisi tanaman padi masih lemah dan kemampuan bersaing dengan gulma masih rendah (Sembodo, 2010), sehingga gulma yang tumbuh pada minggu ini harus di Identifikasi agar dapat dikendalikan dengan efektif. Gulma yang tumbuh diamati, kemudian diidentifikasi secara morfologis sesuai dengan buku referensi dan bantuan kunci determinasi dari buku Flora.

\section{HASIL DAN PEMBAHASAN}

Berdasarkan penelitian yang telah dilakukan di lahan sawah padi Kecamatan Rimau, Banyuasin, Sumatera Selatan, diperoleh komposisi gulma sebanyak 15 jenis yang tergolong ke dalam 6 famili (tabel 1). 
Tabel 1. Komposisi Gulma Padi (Oryza sativa L.) di Sumatra Selatan Kecamatan Rimau, Banyuasin

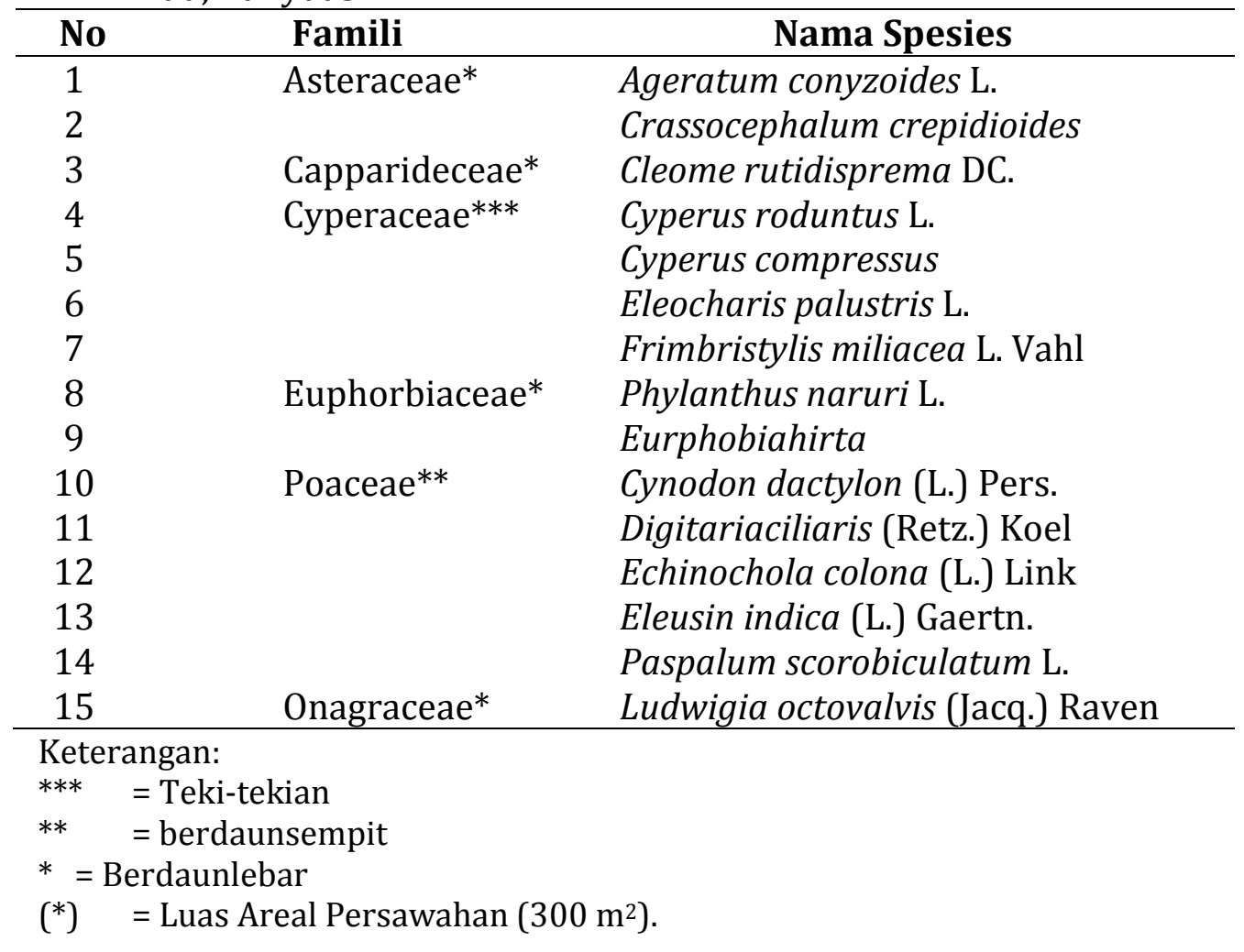

Gulma adalah golongan tumbuhan yang hidup bersama dengan ekosistem pertanian yang mendatangkan kerugian sepanjang sejarah budidaya pertanian. Pengelolaan gulma secara modern sangat memerlukan pengetahuan dasar sifat biologi dan ekologi gulma. Adanya berbagai definisi dan dekripsi gulma menunjukkan bahwa golongan gulma mempunyai kisaran karakter luas dan mempunyai konsekuensi dalam pemberantasan dan pengelolaannya.

Hasil penelitian (tabel 1) ditemukan gulma sebnyak 6 famili yang terdiri dari 15 spesies. Gulma dapat digolongkan berdasarkan sifat morfolonginya, yaitu gulma berdaun sempit (grasses), gulma teki-tekian (sedges), gulma berdaun lebar (broad leaves) dan gulma pakis-pakisan (ferns) (Barus, 2003). Jumlah ini tergolong banyak jika dibandingkan dengan beberapa penelitian lainnya seperti 13 spesies gulma pada tanaman padi di Kecamatan Pauh, Kota Padang (Miranda, 2011), spesies gulma ditemukan di lahan sawah padi di Kecamatan Baleendah, Bandung (Antalina, 2012). Perbedaan ini dikarenakan teknik pemeliharan dan varietas padi yang berbeda. Pada penelitian ini diketahui bahwa gulma yang paling banyak ditemukan pada lahan persawahan Kecamatan Rimau Kabupaten Banyuasin adalah famili Poaceae yang terdiri dari 5 spesies. Sedangkan golongan gulma yang paling sedikit ditemukan adalah famili Onagraceae hanya satu jenis.

Pada penelitian ini, golongan gulma berdaun sempit/rumput (grasses) terdapat pada famili Poaceae yang terdiridari Cynodon dactylon (L.) Pers., Digitariaciliaris (Retz.) Koel, Echinochola colona (L.) Link., Eleusin indica (L.) Gaertn., Paspalum scorobiculatum L (Caton, 2011). Kelima spesies memiliki ciri morfologi daun yang khas. Menurut (Barus, 2003), daun gulma golongan ini menyerupai pita, dengan batang tanaman beruas-ruas, tanaman tumbuh tegak atau menjalar dan memiliki pelepah serta helaian daun. 
Golongan gulma teki (sedges) terdapat pada famili Cyperaceae yang terdiri dari Cyperus roduntus L., Cyperus compressus, Eleocharis palustris L., Frimbristylis miliacea L. Vahl. (Caton, 2011). Ciri morfologi daun pada gulma golongan teki menyerupai golongan gulma berdaun sempit, namun memiliki ciri batang yang khas yaitu mendong (hanya terdiri dari satu ruas yang panjang) dan juga berbentuk segitiga (Barus, 2003). Gulma teki mempunyai senyawa allelopati menyebabkan tanaman budidaya sulit tumbuh (Siregar, dkk., 2017).

Golongan gulma berdaun lebar, terdapat pada famili Asteraceae, Capparideceae, Euphorbiaceae, Onagraceae yang terdiri dari beberapa spesies, yaitu Ageratum conyzoides L., Crassocephalum crepidioides, Cleome rutidisprema DC., Phylanthus naruri L., Ludwigia octovalvis (Jacq.) Raven. (Caton, 2011). Ciri khas pada golongan ini terletak pada ukuran daun yang melebar dan tanaman tumbuh tegak atau menjalar (Barus, 2003).

\section{SIMPULAN}

Berdasarkan hasil identifikasi gulma, didapatkan 15 spesies yang tergolong kedalam 6 famili. Famili Poaceae paling banyak ditemukan sebagai gulma tanaman padi di Kecamatan Rimau, Sumatera Selatan.

\section{UCAPAN TERIMA KASIH}

Terimkasih ditujukan kepada LP2M UIN Raden Fatah Palembang telah memberikan hibah dana penelitian pada tahun anggaran 2017.

\section{REFERENSI}

Aldrich, R.J. (1984). Weed-crop Ecology. Principles in Weed Management. Nort Scituate. Massachussets: Breton Publisher

Antralina, M.(2012). Karakteristik Gulma dan Komponen Hasil Tanaman Padi Sawah (Orzya Sativa L,) Sistem SRI Pada Waktu Keberadaan Gulma yang Berbeda. CEFARS : Jurnal Agribisnis dan Pengembangan Wilayah, 3 (2): 9-17.

Bangun, P. d. (1993). Pengendalian Gulma pada Tanaman Padi. In Buku Padi 2. Puslitbangtan: Bogor.

Barus, E. (2003). Pengendalian Gulma di Perkebunan. Yogyakarta: Kanisius.

Biogen. (2000). Biogen. Retrieved from http//biogen.litbang.deptan.go. id/berita. Artikel/Berita 2000. Seminar Hasil 2000. pp.

Caton BP, M. M. (2011). Gulma Padi di Asia. Edisi Kedua. Philippines: IRRI.

Harnel, B. \&. (2011). Kajian Teknis dan Ekonomis Mesin Penyiang (Power Weeder) Padi di Lahan Sawah Tadah Hujan. Jurnal Pengkajian dan Pengembangan Teknologi Pertanian, 1-10.

Pertanian, B. L. (2012). Varietas Padi Unggulan Badan Litbang Pertanian. Retrieved from http://www.litbang.pertanian.go.id/download/one/355/.

Pertanian, P. D. (2016). Outlook Komoditas Pertanian Sub Sektor Tanaman Pangan. Jakarta: Pusat Data dan Sistem Informasi Pertanian.

Sarifin, M., I.P. Sujana \& N.L. Suyasdi Pura. (2017). Identifikasi dan Analisis Populasi Gulma Pada padi sawah organik dan anorganik Di Desa Jatiluwih, Kecamatan Penebel, Kabupaten Tabanan. AGRIMETA, 7(13): 50-55.

Sembodo, D. R. ( 2010). Gulma dan Pengendaliannya. Yogyakarta: Graha Ilmu.

Siregar, E.N., A. Nugroho \& R. Sulistyono. (2017). Uji Alelopati Ekstrak Umbi Teki Pada Gulma Bayam Duri (Amaranthus spinosus L.) dan Pertumbuhan Tanaman 
Jagung Manis (Zea mays L. Saccharata). Jurnal Produksi Tanaman, 5(2):290298.

Sundaru, M. Syam \& M. Bakar, J. (1976). Beberapa Jenis Gulma Padi Sawah. Bogor: Lembaga Pusat Penelitian Pertanian. Buletin Tehnik No. 1. 